\title{
ADOPTING A COGNITIVE INFORMATION PROCESSING APPROACH TO INCREASE STUDENTS' CAREER MATURITY
}

\author{
Rezki Suci Qamaria *, Fidia Astuti \\ Institut Agama Islam Negeri (IAIN) Kediri, Indonesia \\ *e-mail: rezkisuciqamaria@iainkediri.ac.id
}

\begin{abstract}
The results of a survey on students in a university in Kediri found the fact that students are still confused and do not have any idea about their future career even though the study period is almost complete. This might be because they lack knowledge about career options that are appropriate to their field of study, feel less confident about their abilities, lack of self-awareness related to their potential, and do not yet know how to prepare themselves for the work world. These phenomena illustrate the lack of student career maturity. This condition might cause an increase in the unemployment rate or job mismatch. Against this backdrop, we designed and implemented strategies to overcome these problems using a Cognitive Information Processing approach. In particular, we conducted Focus Group Discussions (FGD) with students, implemented career counselling, and carried out career socialization. This research used a pre-experimental design, particularly a one-group pretest and posttest design. The result shows that students experienced a significant increase in their career maturity. Students now have a better picture of career options that match their educational background, have short-term and long-term planning related to career readiness after completing education, and have confidence in their abilities or potential.
\end{abstract}

Keywords: Cognitive information processing, focus group discussion, career counseling, career socialization, career maturity

\section{PENDEKATAN COGNITIVE INFORMATION PROCESSING SEBAGAI SOLUSI UNTUK MENINGKATKAN KEMATANGAN KARIR MAHASISWA}

\begin{abstract}
Abstrak: Hasil survey pada mahasiswa di sebuah perguruan tinggi di Kediri menemukan fakta bahwa mahasiswa masih bingung dan belum memiliki gambaran karir padahal masa studi hampir selesai. Hal tersebut disebabkan kurangnya pengetahuan mahasiswa tentang karir yang sesuai bidang studi yang ditempuh, merasa kurang percaya diri dengan kemampuan yang dimiliki, kurangnya kesadaran diri terkait potensi yang dimiliki, dan mahasiswa belum tahu cara mempersiapkan diri menghadapi dunia kerja. Kondisi tersebut menggambarkan kurangnya kematangan karir mahasiswa. Kondisi mahasiswa jika tidak memiliki gambaran karir adalah berpotensi menambah jumlah pengangguran atau cenderung menggeluti pekerjaan yang tidak seusai dengan latar belakang pendidikannya. Berangkat dari kondisi tersebut, maka peneliti merancang dan melaksanakan strategi mengatasi masalah tersebut dengan pendekatan Cognitive Information Processing yaitu melakukan Focus Group Discussion (FGD) pada mahasiswa, melaksanakan konseling karir, dan melaksanakan sosialisasi karir. Metode penelitian yang yang digunakan adalah pre-eksperimental design dengan jenis one-group pretest and pascatest design. Hasilnya adalah mahasiswa mengalami peningkatan kematangan karir yang signifikan. Setelah diberikan penanganan mahasiswa telah memiliki gambaran karir sesuai latar belakang pendidikannya, mahasiswa memiliki perencanaan jangka pendek dan jangka panjang terkait kesiapan karir setelah menyelesaikan pendidikan, dan mahasiswa memiliki kepercayaan diri terhadap kemampuan atau potensi yang dimilikinya.
\end{abstract}

Kata Kunci: Cognitive information processing, focus group discussion, konseling karir, sosialisasi karir, kematangan karir

\section{INTRODUCTION}

The success of a country in producing quality human resources is very closely related to the participation of education providers such as a uni- versity. The establishment of a university in Kediri, Indonesia, for instance, is aimed to produce graduates who have the skills and personalities that are needed in the world of work. If this aim is achieved, the unemployment rate in Indonesia, especially in the City of Kediri can be reduced. 
The efforts to decrease the unemployment rate is inseparable from the efforts made by higher education institutions to prepare graduates for the world of work. One of these efforts is to create sustainable activities or programs for final-year students about career readiness.

Our preliminary survey study found that of 95 seventh-semester university students in Kediri, $54 \%$ of them had not had a clear career picture even though their study period was almost finished. Many factors might have caused this phenomenon, including students' lack of knowledge about career options that match their field of study. Students felt less confident in their abilities even though their average GPA was 3.3. They also had low self-awareness regarding their potential and did not know how to prepare themselves for the world of work. The conditions experienced by these students illustrate their lack of career maturity.

As a result, when they return to the community, it is likely that they will contribute to the increasing unemployement rate or end up doing jobs that do not match their educational background. One of the missions of the university in Kediri, as stated in the their 2019-2024 stra-tegic plan, is to produce qualified and competitive graduates in the world of work.

These findings show that there is an urgency to solve the problems of career immaturity not only to decrease unemployment rate but also to get a high accreditation score for the university. Accreditation bodies usually look for data regarding the waiting time to first employment, education-job match, and graduates' workplaces. These criteria can predict whether prospective graduates have a clear career picture or readiness to enter the workforce. One of the most pressing problems is the fact that alumni are likely to end up working in a job that does not match their educational background. Besides, those who succeed in the world of work are also usually helped by the network they built.

Career maturity is an individual's ability to make career choices, which include making career decisions, and having a realistic and consistent career choice (Grashinta et al., 2018). The understanding of career maturity is far broader than just job selection because it will involve the ability of individuals both in making career decisions and career planning activities. Career maturity leads to the introduction of a career as a whole, beginning with the introduction of self-potential, understanding the actual employment, and planning to determine the right career choices
(Savickas \& Porfeli, 2011). Two factors that support individual career maturity are attitude and competence. Attitudes, in this case, are different behaviours displayed towards career selection while competencies include personal self-assessment of their potential, individual knowledge of work conditions, and logical steps taken in making decisions to achieve a career (Andre et al., 2019).

Departing from the above conditions, we designed and implemented strategies to overcome these problems based on the competence factor by using the Cognitive Information Processing approach. The Cognitive Information Processing approach was chosen because it has goals that are closely related to the needs of the students of the the university in Kediri. The purpose of the Cognitive Information approach is to direct students to make the right career choices, train them to make problems solving, and train them to make future career choices (Sampson et al., 1999; Walker \& Tracey, 2012). It should be noted that the Cognitive Information Processing approach has been used by practitioners to teach and prepare army candidates to make adjustments to their new careers where a soldier is in a position of transition from civil society to the apparatus responsible for the safety of civil society (Clemens $\&$ Milsom, 2008). In this study, we will also develop students' understanding of the world of work and prepare them to face it according to their desired careers. It is widely known that students will go through an adjustment process from the academic world to the world of work. Along with the rapid development of the research topics, the Cognitive Information Processing approach has also been presented in various forms of interventions to handle different career select-ion cases such as career counselling interventions and career outreach (Sampson, 2017). Handling using the Cognitive Information Processing ap-proach not only enhances students' understanding and career readiness but also increases student selfconfidence regarding career choices they decide (Fan, 2016).

In addition, this approach is also a learning model that refers to the ways in which individuals respond to stimuli from the environment, or-ganize data, identify problems, develop concepts, and use symbols to understand and solve prob-lems (Sampson et al., 2004). One of them is a matter related to career selection. The researchers outline the handling strategy in several activities, namely focus group discussion (FGD) activities, career 
counselling activities, and career descript-tion socialisation activities which are given to final-year students.

The focus group discussion (FGD) was carried out considering the fact that the results of previous studies involving 643 students reveals that both female and male students consider the right career choice as essential. Choosing the right career requires self-awareness and support from other people. To foster self-awareness, individuals can attend FGD (Lamanauskas \& Augienè, 2018). Through FGD, individuals will better understand their needs when making career choices.

In addition, career counselling activities were carried out also to respond to the results of the latest research conducted in Korea involving 496 students, which shows that a high level of career maturity among students is related to their experience of attending career counselling programs carried out by the teaching staff (Seo \& Kim, 2019; Ishak et al., 2020). Meanwhile, the career description socialisation was carried out considering the fact that there is a positive correlation between information obtained related to a career with the achievement of the profession in the future. Professionals explain that they could achieve their dream careers because they were helped to build a better career picture through socialisation activities (Ash Shiddiqy et al., 2019).

The purpose of this study is to find out whether the Cognitive Information Processing approach which involves three activities, namely focus group discussions (FGD), career counseling activities, and career description socialization activities can increase the career maturity of finalyear students. This study predicts that the more effective the use of the Cognitive Information Processing Approach is, the higher the students' career maturity level will become.

\section{METHODS}

The population of this study was 95 seventh-semester students of the Islamic Family Law Study Program, Faculty of Sharia of a uni-versity in Kediri. This research used a purposive sampling technique. The goal was that the samples involved in this study met the characteristics following the research objectives (Arikunto, 2013). The characteristics of the research sample were those who are in the seventh-semester and whose career maturity pretest results are in the medium and low categories.

Furthermore, the design used in this preexperimental design research was a one-group pretest and posttest design. This design included initial measurement of the dependent variable on the respondent before being given treatment and after being given treatment, the researchers remeasured the dependent variable with the same measuring instrument (Stephens et al., 2019). Treatment, in this case, was in the form of Focus Group Discussion (FGD) activities, career counselling activities, and career description socialisation activities that used cognitive information processing approach involving students as the respondents. We chose this design to see whether the treatment with the cognitive information processing approach as outlined in the Focus Group Discussion (FGD) activities, career counselling activities, and career description socialisation activities was able to increase the career maturity of the students in the experimental group. The design of the experiment is illustrated in the following image:

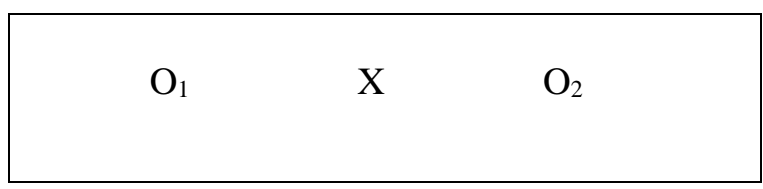

Figure 1. Design of the Experiment

Information:

O1: Pretest measurement

X: Treatment (Focus Group Discussion (FGD), career counselling activities, and career description socialisation activities that use the cognitive information processing approach)

$\mathrm{O} 2$ : Post-Test Measurement

In addition, we also collected the data using questionnaires, observations, and interviews. The questionnaires was about a career maturity adapted from (Chan, 2020). The survey measured four aspects of student career maturity, namely career planning (having confidence in their potential and active participation in career planning), career information exploration (seeking information about careers from competent people and participating in activities that could explore and develop their potential), gathering (knowing their career interests, knowing how to succeed in their career, and understanding the duties and roles in a job), and decision making (making decisions based on knowledge about themselves and being independent in making career decisions). The questionnaire consisted of 39 items with a reliability coefficient of 0.884 (Chan, 2020).

The questionnaire was administered using Google form. We provided information to the students through google classroom by sending a link that can be accessed by students to fill out a career 
maturity questionnaire. Some students filled out the questionnaire using laptops, while others used mobile phones. Of 95 students, only 90 of them were involved in filling out this career mapping scale. Interviews in this study were conducted in an unstructured manner during the research process.

In carrying out activities that use the cognitive information processing approach, we designed an FGD guide that had previously been discussed together with a peer psychologist. Likewise, with the counselling module used in this study is a modification module from a psychologist colleague. The materials presented during the implementation of the socialisation was materials related to the description of careers as advocates, judges, religious instructors, mediators, and lecturers who were prepared by the informational sources.

The first step of data analysis was categorising the results of a career maturity questionnaire. Moreover, the second analysis was comparative analysis (paired sample t-test) related to the description of student career maturity by using SPSS software version 25. Before conducting a comparative analysis, the author first tested assumptions as a prerequisite, namely normality and homogeneity tests. Comparative analysis or often called paired t-test is one of the hypothesis testing methods where the data used are not in pairs but only involves data from one group (Seniati et al., 2005).

\section{FINDINGS AND DISCUSSION}

\section{Findings}

Before carrying out several activities aimed at increasing student career maturity, we first conducted a pre-test to get an overall picture of student career maturity. The initial data results are presented in Figure 2.

The Figure 2 illustrates that of the 90 students who filled out the questionnaire, 43 of them had a high level of career maturity, 45 had a moderate level, and two had a low level. Based on predetermined respondent criteria, namely stu-dents who had low and medium career maturity categories, then the number of students who should be involved in these research activities should be 47 students. However, seven students were unable to participate in a series of events. Therefore, the number of active respondents in this study was only 40 students.

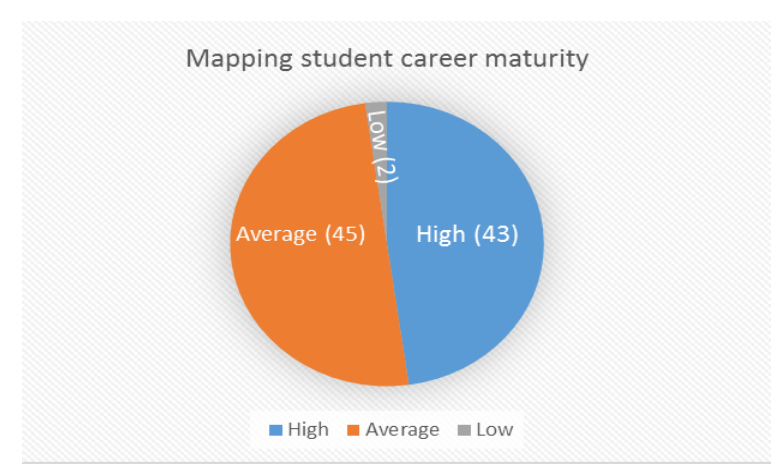

\section{Figure 2. Seventh-Semester Students' Career Mapping Results}

When the research respondents have been determined, the researchers then conducted a focus group discussion (FGD) aimed to explore information related to the student needs that can help students prepare for the desired career after completing undergraduate education. In parti-cular, for this FGD activity, only eight students were involved as representatives/samples. The event aims to dig up information on respondents regarding complaints that make students still experience confusion or not even prepare them-selves to pursue a career path after completing education. The general questions asked by researchers to respondents include the thoughts and feelings of students when instructed to think about a career to be pursued, student constraints in obtaining career-related information according to educational background, students' needs in preparing for the world of work, and how much self-confidence students on their abilities, as well as social support obtained from the environment related to career selection.

During the FGD, all students actively expressed their opinions regarding questions raised. Students are guided to think about a career that they will pursue after completing their education. Three students said that they had thought of a job that would later be sought, but the problem was that their dream job was contrary to the image of a career desired by their parents. For example, SZ had thought that he would later pursue a career as a staff in a religious court. However, her parents, especially her mother, wanted SZ to become a teacher just like her mother's career. SZ felt that she was not able and not interested to be a teacher because she wanted to have a career as a staff/employee. For SZ, she needs an effort to convince her mother to support her to get her dream job. SZ, NA, and MAY also explained that although they had thought about a job that they would pursue later, they did not yet have a picture of what 
things needed to be prepared to pave their way towards that career. They considered that self-preparation was vital because they realized that lecture materials and theories they learned were not enough to prepare themselves without information about the situation and conditions in the field. If they were directed to prepare themselves independently, they certainly would answer that they were still confused about the things that needed to be done.

Different data were obtained from five other female students: AP, AH, LND, CN, and ASI. They said that before the FGD process took place, they had not had a clear career picture. They had no idea what kind of career they would pursue after completing their education. They did not have a career picture because it was based on feelings of insecurity and felt that their abilities were not sufficient enough for a career or in other words, they were not ready to work. Because they did not have a career description, they did not want to make efforts and instead, said that they wanted to let the fate determine the course of their lives. When they were directed to prepare themselves, they were confused as to what to develop themselves and what concrete efforts would have to be taken to convince themselves that they have specific abilities and can be maximised and even utilised in the world of work. Regarding social support, the students also did not have a picture where they would get the help from.

Based on the results of the FGD, we concluded that students need psychological support to increase their confidence in their abilities. Besides, students also need guidance to develop concrete steps that can be taken to prepare themselves for a career in the future. Another need is a description of the jobs they can pursue related to the science majors currently pursued. A requirement that is no less important is the support and direction from the environment; for example, a family is also needed by students to mature their chosen career.

After the FGD activities, the researchers then carried out career group counselling activities. The content of the material in the career group counselling process also discussed the needs of students related to career readiness obtained during the implementation of the FGD. Career group counselling was given to help students recognise themselves and their potential, build self-confidence, and provide training to make concrete steps in preparing for a career to be pursued, as well as providing guidance related to how to obtain social support for career selection by the college student.

We used a career group counselling module with a cognitive information processing approach that had been modified and validated according to the purpose of the activity. Based on the modified module, we conducted counselling in three sessions. The first session focused on students' self-introduction (recognising their nature, potential, and giving appreciation to themselves and building self-confidence). The second session focused on the career selection that will be prepared by the students. The third session focuses on making concrete steps that will be undertaken by students to prepare themselves to pursue selected or desired career paths as well as information on how to obtain social support for career selection by students.

The counselling process was given in groups of 10 people. The total number of students who had career maturity in the medium and low categories who were involved in this study was 40. The number was then divided into four counselling groups, and due to time constraints, the group division was adjusted to the free time of students. All sessions were expected to be able to assist students in determining and preparing themselves to face the world of work after attaining the status of alumni of the university.

The last activity that we carried out was career outreach. The career outreach activities aimed to provide some descriptions of careers that students can pursue based on the current majors. This career description socialization would later involve current alumni as the speakers. It was aimed at not only giving an overview to students but also providing motivation to students/prospective alumni to pursue their career as high as possible that match their interests, abilities, and education background.

The material presented was a real picture of work in the field as advocates, judges, religious instructors, mediators, and lecturers. Speakers not only explained a general description of the types of career, but also shared concrete steps and tips that students can take to achieve their desired job. Based on the number of student attendances and the punctuality of participation, it can be said that students were enthusiastic enough to take part in this socialization activity. Students also actively asked questions so that the information obtained by students was getting wider.

In general, students gave positive testimonials about the implementation of FGD activities, 
career counselling, and career description socialisation. Some testimonials delivered by students; namely, they considered that career counselling activities and career outreach are essential to provide insight and a picture of the real world of work. Besides, some students thought that by participating in a whole series of activities carried out by researchers, they could understand their abilities and could decide on a career to be pursued later. Some students thought that through a series of counselling sessions, he got the right way to convince parents to be able to support their career choices.

After carrying out three sets of activities using the cognitive information processing approach (FGD, counselling, and career outreach), the researchers then collected the final data, which was then mapped as post-test data. Descriptions of the results of the study are show in Figure 3.

Career Maturity Level of students after Participating in Activities (FGD, Career Counseling, Career Socialization)

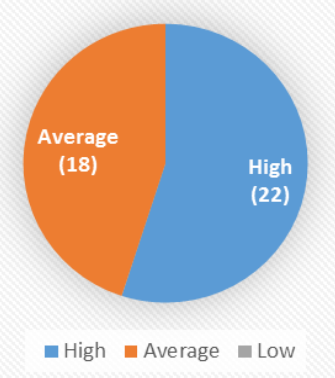

Figure 3. Students' career maturity level after participating in career counselling and career outreach activities

The Figure 3 shows the changes in the level of student career maturity. Before being given treatment in the form of activities that adopted the cognitive information processing approach (FGD, counselling, and career outreach), two research respondents had low career maturity level while 38 were at the moderate level. However, after given treatment with a cognitive information processing approach, there was no student who had low career maturity level, while only 18 students were at a medium level of career maturity, and 22 were at a high level. The following table provides information about a comparison of the career maturity level based on the pre-test and post-test:

In addition to comparative analysis based on Table 1, we also tested assumptions. The results of the Shapiro-Wilk test and Levene's test showed that the pretest and posttest data were in a normal position $(\mathrm{p}=.559, .175>.05)$ and homogeneous $(\mathrm{p}=.062, .055>.05)$. These results mean that the existing data can be analyzed by paired sample t-test to see differences in the conditions of students/respondents before and after being given a series of activities. The results of the analysis are presented as in Table 2.

Table 1. Comparison of Student Maturity Level based on the Pre-test and post-test

\begin{tabular}{ccc}
\hline Category & Pre-test & Post-test \\
\hline High & 0 & 22 \\
Moderate & 38 & 18 \\
Low & 2 & 0 \\
\hline
\end{tabular}

Table 2. Paired Samples Statistics

\begin{tabular}{cccccc}
\hline \multicolumn{5}{c}{ Paired Samoles Corelations } \\
\hline & & Mean & N & $\begin{array}{c}\text { Std. Devi- } \\
\text { ation }\end{array}$ & $\begin{array}{c}\text { Std. } \\
\text { Eror } \\
\text { Mean }\end{array}$ \\
\hline Pair 1 & Before & 105.30 & 40 & 10.557 & 1.669 \\
& After & 118.75 & 40 & 9.818 & 1.552 \\
\hline
\end{tabular}

The Table 2 explains that before students taking part in FGD activities, career counselling, and career outreach, the average career maturity level of 40 students was 105.30. While after the activities, the average level increased by 118.75 . This result means that descriptively there is a difference in the average level of student career maturity before and after participating in the intervention with the cognitive information processing approach.

\section{Table 3. Paired Samples Correlations}

\begin{tabular}{lllll}
\hline \multicolumn{4}{c}{ Paired Samples Correlations } \\
\hline & & N Correlation & Sig. \\
\hline Pair 1 & Before After & 40 & .478 & .002 \\
\hline
\end{tabular}

In addition, the test results show that the correlation between the two variables is 0.478 . The data shows that the association between student career maturity scores before and after participating in career counselling activities and career socialization is substantial and significant. Therefore, researchers interpreted that students experienced significant changes in their knowledge and understanding related to career pre-paration and career selection after following the FGD, career counselling, and career socialization.

Based on analysis per aspect, it is concludeeed that a significant point that experienced an increase is the aspect of career planning, that is, active participation in career planning, the element of independence in making decisions related to careers, the aspects of career exploration that 
was following activities that could develop potential, and points of information gathering.

The additional findings obtained from the results of filling out the worksheet during the group counselling process were data about career descriptions that have been owned by students. The results of these additional data were only obtained from 35 study respondents. The results show that $35 \%$ of students chose to pursue a career as an employee of the Office of Religious Affairs (KUA), $28 \%$ preferred to pursue a career as an employee of the Religious Court (PA), 20\% wanted a career as an advocate and judge, $13 \%$ were self-employed, and four percent were teaching staff (lecturer). The following is an overview of the percentages:

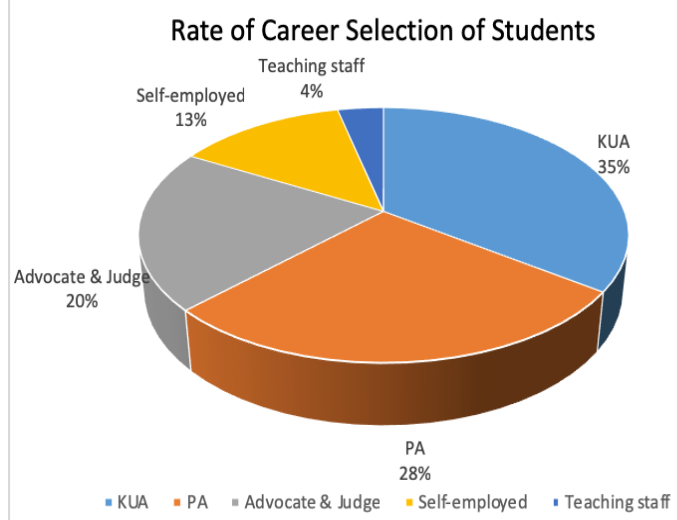

Figure 4. Rate of Career Selection of Students After Following Activities with the Cognitive Information Processing Approach

\section{Discussion}

Interventions with the Cognitive Information Processing approach as outlined in the form of focus group discussion (FGD) activities, career counselling, and career description socialisation at the Faculty of Sharia in a university in Kediri were able to increase student career maturity level significantly. The results of this study reinforce the results of the previous studies conducted by (Nurrega et al., 2018) which concluded that the implementation of activities that use the approach of Cognitive Information Processing are capable of helping individuals to make decisions about a career that matches their educational background. For example, in the results of implementing career counselling in groups with the Cognitive Information Processing approach, students can understand their potential and relate it to the field of work so they have a career picture that will later be cultivated (Nurrega et al., 2018). This condition is also revealed in the series of activities that have been carried out, where students found it helpful to recognise and realise the potential they have had and these potentials can be used and maximised as capital to enter the workforce. Other research conducted also confirmed that activities that use the Cognitive Information Processing approach could help individuals to make the right career choices, learn to improve problem-solving skills and improve career decision making needed for future decisions (Lent et al., 2016).

It should be known together that the Cognitive Information Processing theory is one approach that can be used to explore knowledge about oneself, knowledge of the world of work by potential/ability, and practice individual skills in decision making (Gao et al., 2017; Sampson et al., 1999). Therefore, researchers carried out several activities such as FGD to stimulate students to understand their needs, career counselling to train students' ability to make decisions, and career outreach to provide knowledge and an overview of the working world needed by the students.

In the FGD, students felt a better understanding of what was the obstacle so far in determining a career that made them experience confusion to learn the desired career choice after completing studies. Besides, students also became aware of the urgency in overcoming the difficulty so that they can slowly grow their de-sires and self-confidence to overcome their problem in determining and preparing to pursue the desired career. Evidence that the implementation of the FGD is an effective way to increase students' selfesteem regarding careers to be cultivated is strengthened by the research conducted by (Krisphianti et al., 2019). The results of the study concluded that FGD is one alternative that can be used as a technique to improve students' self-efficacy related to future planned careers (Krisphianti et al., 2019). Increasing self-confidence is the first step to provide students with provisions to better understand their potential and understand how to utilize those potentials properly. It is also confirmed by the results of research conducted by Ning-Kuang Chuang 2020 that students have several developmental tasks, one of which is choosing and preparing for a career. The process of students choosing and preparing for the desired job is a process of student career maturity, and one of the factors that support the career maturity is students' self-confidence related to their potential (Chuang et al., 2020). When a student experiences an increase in confidence, the student's selfconfidence also increases and this has a positive effect on the student's career maturity (Rustanto, 2017). It is known that self-confidence is part of 
forming an individual personality (Purwanta, 2012). So, it can be said that individuals who have high career maturity are those who have an active personality characterised by high self-confidence. This is in line with the previous studies involving 70 students as research respondents which concluded that individuals who have enthusiastic characters significantly predict individual career maturity and minimise the doubt to make a career selection (Park, 2015). Related to the confidence of students who also experienced an increase, this also had a positive influence on the increased ability of students to choose and prepare for their desired careers. Having a self-confidence can predict the stability of individual career choices (van der Werff et al., 2019).

The results of the FGD implementation also became one of the researchers' references in carrying out career counselling. Some student needs that were revealed during the application of the FGD can be met through the career counseling process. For example, the need for self-confidence was further enhanced during the counselling process. Career counselling services play an essential role in assisting individuals in gaining confidence in and helping them to maintain chosen career targets (Hamideh et al., 2016).

Through the process of implementing career counselling, students are also increasingly detailed in planning concrete steps that can be taken to achieve the desired career targets through the process of working on a counselling worksheet. This condition is very influential on increaseing student career maturity because based on analysis per aspect, the aspect of student career maturity that significantly increases is the aspect of career planning that is characterised by active student participation in working on worksheets to design concrete steps to achieve the desired career. These results further strengthen the results of previous research that career counselling is effective to improve student career maturity because through career counselling, counsellors can dig up information about student problems, design concrete steps to achieve the desired career, and sources of student support in designing careers to be pursued (Yuksel-Sahina, 2012; Saifuddin et al., 2017). Also, the formation of career orientation in individuals can be done by implementing career counselling that requires individuals to play an active role in presenting ideas and expressing feelings so that individuals with full awareness understand their career choices (Aqmarina et al., 2017; Kolbasin, 2018).
In the counselling process, the discussion also focused on the source of student support related to the career of their choice because not a few students do not get help from the people closest to them, such as parents. Through career counselling, researchers who act as counsellors provide some suggestions so that students can foster support from those around them, especially families. For example, building effective communication with family, inviting parents to discuss related careers to be chosen, or showing high motivation/concrete effort to achieve that career to parents. What researchers did was also supported by the results of previous studies that explained that support from parents and close people emotionally had a very positive effect on self-confidence and individual confidence in determining the career to be cultivated (Noor et al., 2021; Seo \& Kim, 2019; Stringer \& Kerpelman, 2010). One way to get support is by building intense interactions with people who are considered capable of providing career motivation (Jacobs et al., 2019). Even emotional ties with the family greatly influence the style of individual career decision making. Rational decision-making styles are carried out by individuals who have emotional ties that are close to the family while spontaneous career decision-making styles are carried out by individuals who have tenuous and affective relations with family (Pellerone et al., 2015; Suvajdzic, 2016; Yussoff \& Nordin, 2021).

In the implementation of career counselling with the information cognitive processing approach, the researchers gave instructions to students to think about and find career targets that match their potential and educational background. The implementation of career outreach activities also strengthened career counselling activities where speakers in the career outreach activities involved alumni who have career experiences as practitioners and academics in the field of law. This further strengthened students 'understanding of the career they were planning and enriches students' knowledge regarding matters that must be prepared to achieve and pursue the desired job. These findings also reinforced the results of previous studies, namely the existence of work alliances or career-related informants that will be cultivated to be able to add insight into students related to careers that are involved so that it affects the increase in student career maturity (Whiston et al., 2016). The additional information obtained will be processed to be the basis for choosing a career that suits their interests and 
according to the educational background (Schorr, 2019).

\section{CONCLUSION}

The activities that have been carried out by the researchers with the Cognitive Information Processing approach at the Faculty of Sharia in a university in Kediri proved to be able to increase student career maturity level significantly. These activities include focus group discussions (FGD), career counselling, and career outreach. Based on the results of career mapping, preliminary data obtained from 40 students who were actively involved in activities using the Cognitive Information Processing approach, 38 students had career maturity level in the medium category and two in the low category. However, after students took part in a series of activities, the division of student career maturity level significantly changed from the small and moderate groups to the high category.

The final data management results show that of the 40 students who actively participated in the series of activities, 22 students had a high career maturity level, and 18 still had a moderate career maturity level. Thirty-five students have been able to choose the career to be pursued and design concrete steps that will be taken to achieve their career choices. Of the four aspects of career maturity, aspects of career planning (active participation in career planning) that have a significant increase after students went through FGD activities, career counselling, and career outreach.

Through the results of this career maturity improvement, seventh-semester students as prospective alumni are predicted and expected to complete their studies on time and be able to apply the knowledge, skills, and attitudes that have been obtained during their undergraduate education at the Faculty of Sharia, a university in Kediri, in the work world. The existence of alumni in the world of work is one proof of the realisation of the objectives of the university.

Finally, this research is expected to contribute to the study of career maturity and be an alternative solution to improve individual career maturity, especially in students. Bearing in mind that one of the tasks of personal development throughout their life is to pursue a career that match their interests and abilities that are obtained from the educational process.

\section{REFERENCES}

Andre, L., Peetsma, T. T. D., van Vianen, A. E. M., Jansen in de Wal, J., Petrović, D. S., \&
Bunjevac, T. (2019). Motivated by future and challenges: A cross-cultural study on adolescents' investment in learning and career planning. Journal of Vocational Behavior, 110, 168-185. https://doi.org/https://doi.org/10.1016/j.jvb. 2018.11.015

Aqmarina, F. N., Sahrani, R., \& Hastuti, R. (2017). Konseling karir dengan menggunakan career informationprocessing model untuk membantu career decision-making. Psympathic: Jurnal Ilmiah Psikologi, 4(1), 21-34. https://doi.org/10.15575/psy.v4i1.1265

Arikunto, S. (2013). Prosedur penelitian suatu pendekatan praktik. Rineka Cipta.

Ash Shiddiqy, A. R., Suherman, U., \& Agustin, M. (2019). Efektivitas bimbingan karier terhadap kematangan karier mahasiswa. Indonesian Journal of Educational Counseling, 3(3), 301-311. https://doi.org/10.30653/001.201933.115

Chan, C.-C. (2020). Social support, career beliefs, and career self-efficacy in determination of Taiwanese college athletes' career development. Journal of Hospitality, Leisure, Sport \& Tourism Education, 26, 100232. https://doi.org/10.1016/j.jhlste.2019.10023 2

Chuang, N.-K., Lee, P. C., \& Kwok, L. (2020). Assisting students with career decisionmaking difficulties: Can career decisionmaking self-efficacy and career decisionmaking profile help? Journal of Hospitality, Leisure, Sport \& Tourism Education, 26, 100235. https://doi.org/10.1016/j.jhlste.2019.10023 5

Clemens, E. V., \& Milsom, A. S. (2008). Enlisted service members' transition into the civilian world of work: A cognitive information processing approach. The Career Development Quarterly, 56(3), 246-256. https://doi.org/10.1002/j.21610045.2008.tb00039.x

Fan, J. (2016). The role of thinking styles in career decision-making self-efficacy among university students. Thinking Skills and Creativity, 20, 63-73. https://doi.org/10.1016/j.tsc.2016.03.001

Gao, Y., Feng, Y., \& Tan, J. (2017). Exploratory study on cognitive information gain 
modeling and optimization of personalized recommendations for knowledge reuse. Journal of Manufacturing Systems, 43, 400-408. https://doi.org/10.1016/j.jmsy.2017.01.003

Grashinta, A., Istiqomah, A. P., \& Wiroko, E. P. (2018). Pengaruh future time perspective terhadap kematangan karir pada mahasiswa. Jurnal Psikologi Pendidikan Dan Konseling: Jurnal Kajian Psikologi Pendidikan Dan Bimbingan Konseling, 4(1), 25. https://doi.org/10.26858/jpkk.v4i1.4981

Hamideh, A., Parisa, N., Reza, A. M., \& Simin, H. (2016). Effect of career counseling method based on social-cognitive theory, constructive, motivational on students'career engagement. Counseling Culture and Psychotherapy.

Ishak, N., Hasibuan, R. R., \& Arbani, T. S. (2020). Bureaucratic and political collaboration towards a good governance system. BESTUUR, 8(1), 19. https://doi.org/10.20961/bestuur.v8i1.4292 2

Jacobs, S., De Vos, A., Stuer, D., \& Van der Heijden, B. I. J. M. (2019). "Knowing me, knowing you" the importance of networking for freelancers' careers: examining the mediating role of need for relatedness fulfillment and employabilityenhancing competencies. Frontiers in Psychology, 10. https://doi.org/10.3389/fpsyg.2019.02055

Kolbasin, V. N. (2018). ПЕДАГОГИЧЕСКИЕ УСЛОВИЯ ФОРМИРОВАНИЯ КАРЬЕРНЫХ ОРИЕНТАЦИЙ У ЖЕНЩИН, ЗАНЯТЫХ В СОЦИАЛЬНОЙ СФЕРЕ. Sovremennye Issledovaniya Sotsialnykh Problem, 9(11), 128. https://doi.org/10.12731/2218-74052018-11-128-140

Krisphianti, Y. D., Setyaputri, N. Y., \& Dhian P, I. Y. (2019). Penggunaan focus group discussion (FGD) dengan proses ground, understand, revise, and use (guru) terhadap efikasi diri karier mahasiswa. Universitas Negeri Malang.

Lamanauskas, V., \& Augienè, D. (2018). Lithuanian gymnasium students' career and professional self-determination. Psychological Thought, 11, 148-173. https://doi.org/10.5964/psyct.v11i2.30
Lent, R. W., Ezeofor, I., Morrison, M. A., Penn, L. T., \& Ireland, G. W. (2016). Applying the social cognitive model of career selfmanagement to career exploration and decision-making. Journal of Vocational Behavior, 93, 47-57. https://doi.org/10.1016/j.jvb.2015.12.007

Noor, H. J., Afkar, K., \& Glaser, H. (2021). Application of sanctions against state administrative officials in failure to implement administrative court decisions. BESTUUR, 9(1), 72. https://doi.org/10.20961/bestuur.v9i1.4968 6

Nurrega, R. G., Wahyuningsih, H., \& Gusniarti, U. (2018). Konseling karir kelompok cognitive information processing untuk meningkatkan pengambilan keputusan karir siswa. Journal of Psychological Science and Profession, 2(1), 127. https://doi.org/10.24198/jpsp.v2i1.16702

Park, I.-J. (2015). The role of affect spin in the relationships between proactive personality, career indecision, and career maturity. Frontiers in Psychology, 6 . https://doi.org/10.3389/fpsyg.2015.01754

Pellerone, M., Passanisi, A., \& Bellomo, M. (2015). Identity development, intelligence structure, and interests: a cross-sectional study in a group of Italian adolescents during the decision-making process. Psychology Research and Behavior Management, 239. https://doi.org/10.2147/PRBM.S88631

Purwanta, E. (2012). Faktor yang memengaruhi eksplorasi karier siswa SLTP. Jurnal Cakrawala Pendidikan, 60(2), 228-243. https://doi.org/10.21831/cp.v5i2.1559

Rustanto, A. E. (2017). Kepercayaan diri dan efikasi diri terhadap kematangan karir mahasiswa di Politeknik LP3I Jakarta Kampus Jakarta Utara. JURNAL LENTERA BISNIS, 5(2), 1. https://doi.org/10.34127/jrlab.v5i2.31

Saifuddin, A., Ruhaena, L., \& Pratisti, W. D. (2017). Meningkatkan kematangan karier peserta didik sma dengan pelatihan reach your dreams dan konseling karier. Jurnal Psikologi, 44(1), 39. https://doi.org/10.22146/jpsi.17378

Sampson, J. P. (2017). Cognitive information processing (CIP) theory: challenges and opportunities for integrating theory, 
research, and practice. In Integrating

Theory, Research, and Practice in

Vocational Psychology: Current Status and

Future Directions. Florida State University

Libraries.

https://doi.org/10.17125/svp2016.ch5

Sampson, J. P., Lenz, J. G., Reardon, R. C., \& Peterson, G. W. (1999). A cognitive information processing approach to employment problem solving and decision making. The Career Development Quarterly, 48(1), 3-18.

https://doi.org/10.1002/j.2161-

0045.1999.tb00271.x

Sampson, J. P., Reardon, R. C., Peterson, G. W., \& Lenz, J. G. (2004). Career counseling and services: A cognitive information processing approach.

Thomson/Brooks/Cole Belmont, CA.

Savickas, M. L., \& Porfeli, E. J. (2011).

Revision of the career maturity inventory. Journal of Career Assessment, 19(4), 355374.

https://doi.org/10.1177/1069072711409342

Schorr, A. (2019). Pipped at the post:

Knowledge gaps and expected low parental IT competence ratings affect young women's awakening interest in professional careers in information science. Frontiers in Psychology, 10. https://doi.org/10.3389/fpsyg.2019.00968

Seo, J., \& Kim, M. (2019). A prediction model of factors related to career maturity in Korean high school students. Child Health Nursing Research, 25(2), 95-102. https://doi.org/10.4094/chnr.2019.25.2.95

Stephens, R. G., Matzke, D., \& Hayes, B. K. (2019). Disappearing dissociations in experimental psychology: Using state-trace analysis to test for multiple processes. Journal of Mathematical Psychology, 90, 3-22.

https://doi.org/10.1016/j.jmp.2018.11.003
Stringer, K. J., \& Kerpelman, J. L. (2010). Career identity development in college students: decision making, parental support, and work experience. Identity, 10(3), 181-200. https://doi.org/10.1080/15283488.2010.496 102

Suvajdzic, K. (2016). The differences in selfefficacy in career decision-making and decision-making styles among secondary school students with different patterns of family attachment. Psiholoska Istrazivanja, 19(2), 205-221. https://doi.org/10.5937/PsIstra1602205S

van der Werff, L., Freeney, Y., Lance, C. E., \& Buckley, F. (2019). A trait-state model of trust propensity: Evidence from two career transitions. Frontiers in Psychology, 10. https://doi.org/10.3389/fpsyg.2019.02490

Walker, T. L., \& Tracey, T. J. G. (2012). The role of future time perspective in career decision-making. Journal of Vocational Behavior, 81(2), 150-158. https://doi.org/10.1016/j.jvb.2012.06.002

Whiston, S. C., Rossier, J., \& Barón, P. M. H. (2016). The working alliance in career counseling. Journal of Career Assessment, 24(4), 591-604. https://doi.org/10.1177/1069072715615849

Yuksel-Sahina, F. (2012). School counselors' assessment of the psychological counseling and guidance services they offer at their schools. Procedia - Social and Behavioral Sciences, 47, 327-339. https://doi.org/10.1016/j.sbspro.2012.06.65 9

Yussoff, S. F. B. C., \& Nordin, R. (2021). Freedom of expression in Malaysia: Compatibility with the international human rights standard. BESTUUR, 9(1), 44. https://doi.org/10.20961/bestuur.v9i1.5163 7 